\title{
PENINGKATAN HASIL BELAJAR IPS TEMA INDAHNYA KERAGAMAN DI NEGERIKU \& DAERAH TEMPAT TINGGALKU DENGAN MENGGUNAKAN MODEL COURSE REVIEW HORAY SISWA KELAS IV UPT. SD NEGERI 21 LIMO KAUM
}

\section{HAMIDAR}

hamidar21@gmail.com

\begin{abstract}
This study aims to determine the use of the Course Review Horay (CRH) learning model in improving learning outcomes in Social Sciences (IPS). SD Negeri 21 Limo Kaum. This research is a Classroom Action Research (PTK). This PTK uses the Kemmis and McTaggart model which consists of planning, implementing actions, observing, reflecting. This research was conducted in two cycles, and each cycle of two meetings. The subjects of this study were students of class IV UPT. SD Negeri 21 Limo Kaum, amounting to 31 students. The methods used to collect data include tests, observation and documentation. The data analysis technique used is qualitative analysis techniques. The results of the study using the Course Review Horay learning model improved social studies learning outcomes The Beautiful Theme of Diversity in My Country \& the Areas where I live for grade IV students at UPT. SD Negeri 21 Limo Kaum. This can be seen from the test of student learning outcomes reaching KKM above $75 \%$. In the pre-cycle the class average value was 69.20 with completeness $45.16 \%$ In the first cycle the class average score reached 74.19 with $67.74 \%$ completeness. with completeness $87.10 \%$ based on these results the study was stopped in cycle II. Based on the results of the research, the use of the Course Review Horay learning model can improve social studies learning outcomes. The theme of the beauty of diversity in my country \& the area where I live for grade IV students at UPT. SD Negeri 21 Limo Kaum.
\end{abstract}

Keywords: Learning outcomes, Social Studies and Course Review Horay.

Abstrak: Penelitian ini bertujuan untuk mengetahui penggunaan model pembelajaran Course Review Horay (CRH) dalam meningkatkan hasil belajar Ilmu Pengetahuan Sosial (IPS) Tema Indahnya Keragaman di Negeriku \& Daerah Tempat Tinggalku kelas IV di UPT. SD Negeri 21 Limo Kaum. Penelitian ini merupakan Penelitian Tindakan Kelas (PTK). PTK ini menggunakan model Kemmis dan McTaggart yang terdiri dari perencanaan, pelaksanaan tindakan, observasi, refleksi. Penelitian ini dilaksanakan dalam dua siklus, dan tiap siklus dua pertemuan. Subjek penelitian ini merupakan siswa kelas IV UPT. SD Negeri 21 Limo Kaum yang berjumlah 31 siswa. Metode yang digunakan untuk mengumpulkan data meliputi tes, observasi dan dokumentasi. Teknik analisis data yang digunakan ialah teknik analisis kualitatif.Hasil penelitian dengan menggunakan model pembelajaran Course Review Horay meningkatkan hasil belajar IPS Tema Indahnya Keragaman di Negeriku \& Daerah Tempat Tinggalku siswa kelas IV di UPT. SD Negeri 21 Limo Kaum. Hal tersebut dilihat dari tes hasil belajar siswa mencapai KKM diatas 75\%. Pada Pra-siklus nilai rata-rata kelas ialah 69,20 dengan ketuntasan 45,16\% Pada siklus I nilai rata-rata kelas mencapai 74,19 dengan ketuntasan $67,74 \%$.Pada siklus II nilai rata-rata kelas mencapai 81,94 dengan ketuntasan 87,10\% berdasarkan hasil tersebut penelitian dihentikan pada siklus II. Berdasarkan hasil penelitian penggunaan model pembelajaran Course Review Horay dapat meningkatkan hasil belajar IPS Tema 
Indahnya Keragaman di Negeriku \& Daerah Tempat Tinggalku siswa kelas IV di UPT. SD Negeri 21 Limo Kaum Kecamatan Lima Kaum Kabupaten Tanah Datar

Kata kunci : Hasil belajar, IPS dan Course Review Horay.

\section{A.Pendahuluan}

Pendidikan merupakan salah satu aspek penting dalam kehidupan manusia. Pendidikan memberikan peran dalam mengembangkan, mem-bangun, dan membentuk manusia. Disamping itu pendidikan sudah ada semenjak manusia ada di bumi ini, dan berkembang seiring dengan berkembangnya manusia. Pendidikan tidak lepas dari perkembangan umat manusia, melalui pendidikan manusia berkembang untuk menuju kedewasaan. Di Indonesia pendidikan sangat penting dan memiliki tujuan nasional bagi seluruh bangsa Indonesia. Hal itu tertuang dalam tujuan pendidikan di Indonesia seperti dalam Undang-undang Nomor 20 Tahun 2003 pasal 1 ayat (1) tentang Sistem Pendidikan Nasional, bahwa

Pendidikan adalah usaha sadar dan terencana untuk mewujudkan suasana belajar dan proses belajar agar peserta didik secara aktif membangun potensi dirinya untuk memiliki kekuatan spiritual keagamaan, pengendalian diri, kepribadian, kecerdasan, akhlak mulia serta keterampilan yang diperlukan dirinya, masyarakat, bangsa dan negara. Dari pengertian pendidikan diatas maka pendidikan di Indonesia berusaha untuk mencerdaskan seseorang dari berbagai aspek kehidupan, seperti sosial, budaya, pengetahuan danlainnya. Dalam hal itu pendidikan di sekolah dasar juga bertujuan untuk mengembangkan peserta didik menjadi manusia yang semakin baik. Di sekolah dasar terdapat berbagai mata pelajaran seperti IPA, IPS, Bahasa Indonesia, Matematika, PKn, Agama, Olahraga, dan muatan lokal. Kedudukan mata pelajaran baik dalam kurikulum 2004, Kurikulum 2006, maupun Kurikulum 2013 tetaplah sama, yaitu bertujuan untuk mengembangkan aspek kognitif, afektif, dan psikomotorik.

Pembelajaran IPS merupakan salah satu pembelajaran yang mana dapat digunakan untuk mengembangkan aspek kognitif, afektif dan psikomotorik siswa. Namun terkadang pada kenyataanya saat ini pembelajaran IPS masih mengedepankan aspek kognitif untuk dikuasai siswa.Seperti menurut Sumaatmadja (2006: 1.31) bahwa siswa hafal materi IPS yang diperoleh di sekolah, namun tidak mengetahui hal tersebut dalam kehidupan sahari-hari. Seperti juga penelitian dari Setiawan (Wahidmurni, 2017: 28) yang menemukan permasalahan dalam pembelajaran IPS di SMK diantaranya 1) membolos, 2) meninggalkan kelas saat diberi tugas mencatat, 3) mengantuk atau ketiduran saat guru menerangkan 4) mengobrol dengan teman sebangku. Dari temuan masalahnya, hal demikian terjadi karena guru sering menggunakan metode ceramah. Menurut Pusat kurikulum atau puskur (Wahidmurni, 2017: 28) kendala tersebut memunculkan kecenderungan pemahaman IPS adalah pembelajaran hafalan, pemahaman ini mengakibatkan pembelajaran lebih menekankan pada verbalisme. Dan guru lebih banyak menggunakan metode ceramah bahkan menyuruh siswa untuk mencatat. Guru melakukan pembelajaran yang kurang variatif

Hal tersebut juga ditemui di UPT. SD Negeri 21 Limo Kaum, Kecamatan Lima Kaum dimana dalam kegiatan pembelajaran dengan materi IPS masih sering bersifat satu arah. Serta masih belum dilaksanakan dengan maksimal. Berdasarkan hasil observasi yang sudah dilakukan di UPT. SD Negeri 21 Limo Kaum, ditemukan beberapa permasalah dalam proses pembelajaran di kelas, salah satunya adalah pada materi IPS Tema Indahnya Keragaman di Negeriku \& Daerah Tempat Tinggalku. 
Beberapa permasalahan dalam pembelajran IPS tersebut diantaranya ialah sebagai berikut: Siswa kebingungan dengan materi. Siswa sering kebingungan dengan materi IPS Tema Indahnya Keragaman di Negeriku \& Daerah Tempat Tinggalku yang diajarkan di sekolah, berdasarkan wawancara dengan guru, orangtua siswa juga mengalami kesulitan ketika mangajari anak di rumah. Dan luas serta kompleksnya materi IPS cukup berat bagi siswa. Serta materi yang muncul dalam ujian terkadang jauh melenceng dari materi yang ada dalam buku dan yang disampaikan dalam pembelajaran. Siswa ketika ditanya sering lupa materi yang sudah diajarkan sampai mana dan apa saja yang dipelajarai.

Siswa kurang motivasi belajar. Siswa memiliki motivasi belajar yang kurang dikarenakan rasa bosan, menurut pendapat dari siswa, guru lebih banyak menerangkan dan memberikan tugas, sehingga siswa tidak begitu antusias terutama ketika pembelajaran menginjak siang hari. Terakadang siswa bosan dengan kegiatan pembelajaran yang bersifat monoton sehingga siswa banyak yang mengobrol dengan teman. Siswa kurang aktif selama pembelajaran IPS. Berdasarkan hasil wawancara siswa kurang begitu aktif untuk bertanya, namun cukup terlibat aktif dalam berkelompok meskipun ada juga siswa yang sangat pasif di kelas. Hal ini dikarenakan juga siswa kesulitan menerima dan memahami materi yang diajarkan. Ketika diberi pertanyaan tidak banyak siswa yang antusias untuk menjawab, Ketika berkelompok banyak siswa yang hanya mengandalkan temannya dan enggan untuk memberikan pendapat. Keterampilan sosial siswa juga kurang dan masih tergolong rendah, ini ditunjukkan dengan siswa yang enggan menghargai teman kelasnya, tidak suka berkelompok dengan beberapa siswa lain yang tidak disenangi, dan lainnya.

Guru lebih sering menggunakan metode ceramah dan penugasan dalam melakukan kegiatan pembelajaran. Didasarkan pada hasil wawancara dengan guru, guru lebih banyak menyampaikan materi di depan kelas, serta menggunakan buku sebagai bahan acuuan utama. Meskipun terkadang guru menggunakan metode penugasan maupun metode diskusi, namun lebih sering menggunakan menggunakan ceramah dan penugasan. Guru jarang menggunakan media pembelajaran selama di kelas. Berdasarkan hasil wawancara guru hanya menggunakan media pembelajaran bila perlu, dan lebih banyak menggunakan gambar. Media yang paling sering digunakan ialah peta, dan gambar yang dicari oleh guru, serta belum menggunakan media seperti chart, audiovisual maupun lainnya. Penggunaan media pembelajaran realia beberapa kali digunakan namun hanya dalam mata pelajaran SBdP.

Keterampilan sosial siswa yang rendah. Hal ini ditunjukkan dengan hasil observasi dimana siswa kurang mampu menghargai perbedaan yang dimiliki teman, enggan untuk berkelompok dengan teman yang dianggap tidak pintar. Dalam berkelompok siswa sulit untuk saling bertukar pendapat, dan justru mengandalkan teman. Hasil belajar siswa yang tidak stabil. Ini didasarkan pada nilai keseharian siswa yang selalu naik turun. Hasil belajar ini menurut guru dikarenakan siswa kebingungan dengan materi, dan orangtua juga turut kebingungan dalam mengajarkan materi pada anak. Untuk hasil belajar ulangan harian terdapat beberapa materi yang siswa cukup rendah. Nilai rata-rata ulangan harian IPS pada tema Tema Indahnya Keragaman di Negeriku \& Daerah Tempat Tinggalku diantara keseluruhan mata pelajaran yaitu 62,90

Berdasarkan pada beberapa permasalahan yang ditemukan di UPT. SD Negeri 21 Limo Kaum, tersebut maka masalah yang diambil akan dibatasi pada hasil belajar IPS. Penelitian difokuskan pada hasil belajar IPS yang masih rendah. IPS dipilih dikarenakan selain nilai siswa dalam pembelajaran IPS masih rendah juga karena EISSN 2657-0289 $\quad$ Lembaga Penelitian dan Penerbitan Hasil Penelitian Ensiklopedia 3 
masih terdapat beberapa hal yang belum tercapai. Kompetensi sosial anak dalam pembelajaran IPS masih belum terlihat secara maksimal seperti rendahnya kerjasama dalam berkelompok, pemahaman materi IPS yang bagi siswa masih membingungkan, serta mudahnya motivasi dan perhatian siswa teralihkan.

Model pembelajaran yang dipilih untuk memberikan solusi ialah model pembelajaran Course Review Horay. Model pembelajaran ini ialah model pembelajaran kooperatif dan aktif, dengan melibatkan kelompok. Model pembelajaran ini menjadikan suasana kelas meriah dan menyenangkan menurut Kurniasih dan Sani (2015: 80) Model pembelajaran ini dapat menarik perhatian dan partisipasi siswa karena terdapat yel-yel untuk setiap kali menjawab benar. Kelebihan model pembelajaran ini ialah pembelajaran yang tidak monoton karena terdapat hiburan berupa yel-yel. Siswa menjadi termotivasi dalam menjawab dengan benar, serta melatih kerjasama tim. Hal ini sesuai dengan karekteristik siswa SD yang memiliki karakteristik senang bermain, senang bergerak dan berkelompok. Sesuai juga dengan karakter anak di kelas IV yang senang berkelompok dan bermain.

Berdasarkan uraian masalah pada proses pembelajaran IPS yang ditemukan di UPT. SD Negeri 21 Limo Kaum serta beberapa uraian lain diatas, maka peneliti ingin meningkatkan hasil belajar IPS Tema Indahnya Keragaman di Negeriku \& Daerah Tempat Tinggalku dengan menggunakan model pembelajaran Course Review Horay. Maka diambil judul penelitian "Peningkatan Hasil Belajar IPS Tema Indahnya Keragaman di Negeriku \& Daerah Tempat Tinggalku dengan Menggunakan Model Course Review Horay Siswa Kelas IV UPT. SD Negeri 21 Limo Kaum”. Diharapkan dengan menggunakan model pembelajaran Course Review Horay dapat meningkatkan hasil belajar IPS di kelas IV UPT. SD Negeri 21 Limo Kaum. Berdasarkan hasil uraian latar belakang di atas maka permasalahan yang ditemukan di sekolah dapat diidentifikasikan sebagai berikut: 1) Siswa kebingungan dan kesulitan dengan materi IPS; 2) Kurangnya motivasi belajar siswa di kelas; 3) Siswa yang kurang aktif selama pembelajaran; 4) Guru yang lebih banyak menggunakan metode ceramah dan penugasan dalam pembelajaran IPS; 5) Guru jarang menggunakan media pembelajaran di kelas; 6) Hasil belajar IPS siswa yang belum maksimal, dan seringnya kegiatan remidial; dan 7) Keterampilan sosial siswa yang rendah.

\section{B. Metodologi Penelitian}

Desain penelitian tindakan kelas (PTK) yang digunakan dalam penelitian ini menggunakan model spiral oleh Kemmis dan Mc. Taggart, model ini merupakan pengembangan dari model Kurt Lewin (Kusuma \& Dwigatama, 2010:27). Model ini meliputi yang meliputi empat komponen diantaranya, perencanaan (planning), tindakan (action), pengamatan (observe), dan refleksi (reflection) yang dibentuk dalam rangkaian yang saling terkait antara langkah yang satu dengan langkah yang lain. UPT. SD Negeri 21 Limo Kaum merupakan sekolah dasar yang terletak di wilayah nagari limo kaum, Kecamatan Lima Kaum, Kabupaten Tanah Datar. Dalam penelitian ini, yang menjadi subjek penelitian ialah siswa kelas IV UPT. SD Negeri 21 Limo Kaum. Dengan jumlah siswa di kelas IV ialah sebanyak 31 anak dengan 16 perempuan dan 15 laki-laki. Berdasarkan hasil pengamatan siswa kelas IV akan aktif mengikuti pelajaran apabila kegiatan pembelajaran menarik motivasinya belajar, seperti dengan menggunakan permainan, dan media. Di kelas IV karakteristik setiap anak juga berbeda-beda, dengan latar belakang serta kemampuan kognitif yang berbeda-beda pula. Ada beberapa anak yang sangat pasif di kelas, dan terdapat anak 
yang cukup aktif di kelas. Dan ada seorang anak yang mengalami kesulitan belajar atau di bawah rata-rata. Pada tahapan ini guru melaksanakan tindakan yang sebelumnya sudah dirancang bersama dengan peneliti, yaitu pembelajaran IPS dengan menggunakan model pembelajaran Course Review Horay. Pelaksanaan tindakan dilakukan sesuai dengan skenario tindakan yang sudah dibuat. Pelaksanaan tindakan dilakukan oleh guru dengan berdasar pada RPP yang sudah dibuat peneliti bersama guru dengan model pembelajaran Course Review Horay, dengan posisi peneliti selama pelaksanaan sebagai observator kegiatan pembelajaran dengan model Course Review Horay. Pada tahap I ini observasi dilaksanakan bersamaan dengan pelaksanaan tindakan. Pada pelaksanaan tindakan pembelajaran IPS dengan menggunakan model pembelajaran Course Review Horay, dilakukan observasi dengan membuat lembar observasi terhadap aktivitas siswa dan guru selama proses pembelajaran IPS dengan menggunakan model pembelajaran Course Review Horay tersebut. Kegiatan observasi ini dilakukan untuk mengetahui apakah terdapat kendala atau tidak dalam pelaksanaan tindakan. Selain itu, untuk mengetahui apakah tindakan yang dilakukan sudah sesuai dengan indikator ataukah masih belum Dalam tahap ini guru dan peneliti menganalisis data hasil observasi untuk mencari kemungkinan penyebab terjadinya hambatan selama pelaksanaan tindakan. Dari kegiatan tersebut akan menghasilkan sebuah kesimpulan mengenai sejauh mana ketercapaian tujuan penelitian. Apabila yang didapatkan bahwa hasilnya tidak memenuhi kriteria keberhasilan yang ditetapkan, maka peneliti dan guru melakukan perbaikan yang dilakukan pada siklus II. Pada siklus II proses perancangan akan dikembangkan terutama dalam penyusunan dan pembuatan RPP untuk pelaksanaan siklus II. Penyusunan dan perancangan siklus II dilaksanakan berdasaran pada hasil refleksi dari siklus I.

\section{Hasil dan Pembahasan \\ Deskripsi Kondisi Awal}

Data diperoleh dari siswa kelas IV UPT. SD Negeri 21 Limo Kaum, Kecamatan Lima Kaum Kabupaten Tanah Datar. Dalam penelitian ini sebelum dilaksanakan tindakan terlebih dahulu peneliti melaksanakan kegiatan Pre-test untuk mengetahui data awal hasil belajar siswa kelas IV. Data hasil belajar siswa disajikan untuk setiap siklusnya sehingga dapat dilihat hasil peningkatan untuk setiap indikator. Di bawah ini merupakan data hasil pra-siklus yang sudah dilaksanakan. 
Tabel Hasil Belajar Siswa Kelas IV Pra-Siklus

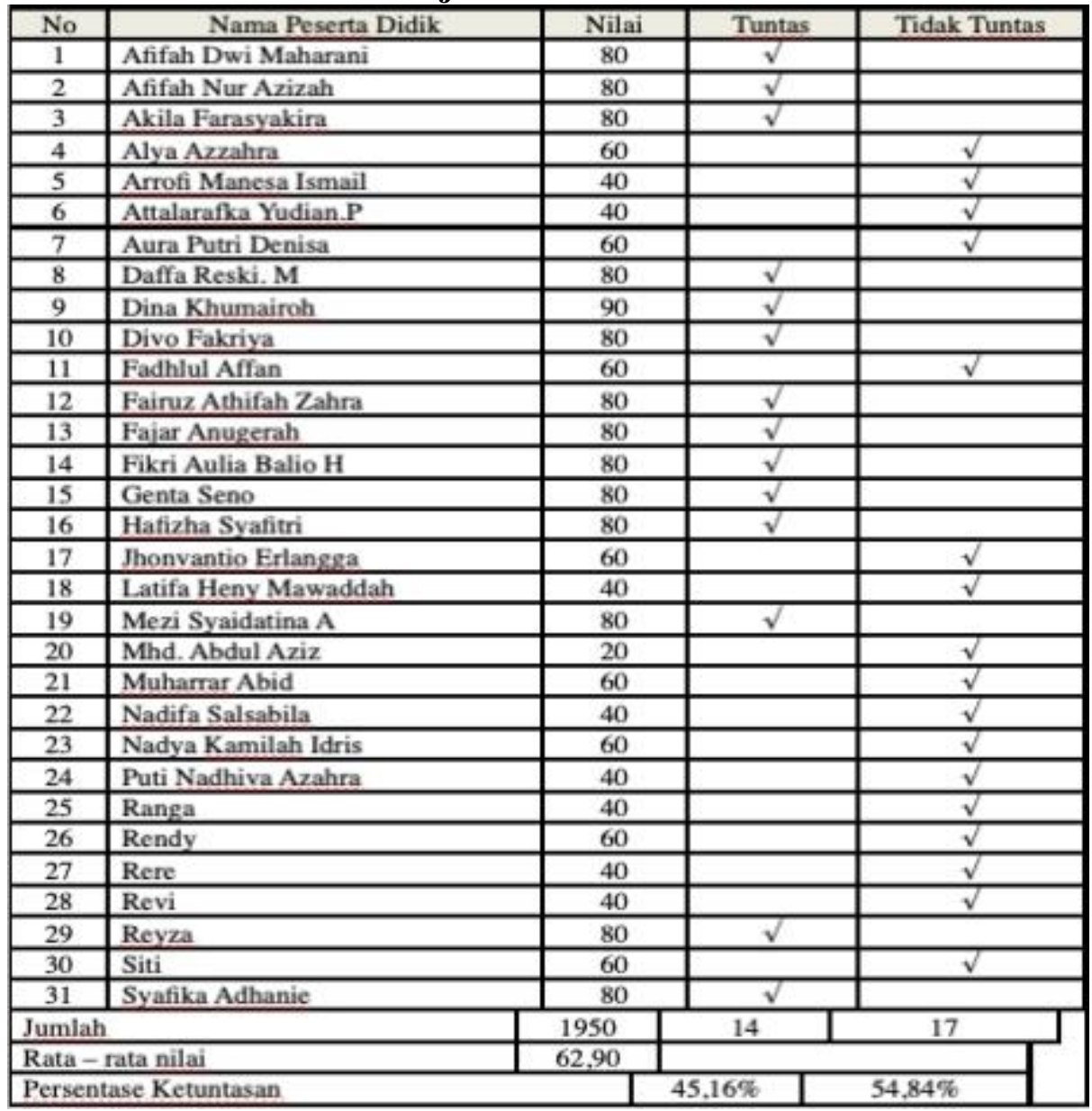

Berdasarkan data tersebut diketahui bahwa ketuntasan belajar siswa pada pratindakan ialah sebesar 45,16\%. Siswa yang mendapatkan nilai tuntas sebanyak 14 siswa dari 31 siswa yang ada di kelas IV. Hasil belajar rata-rata siswa pada pratindakan ini sebesar 62,90, hal ini menunjukkan hasil belajar siswa dalam pembelajaran IPS Tema Indahnya Keragaman di Negeriku masih rendah, serta beberapa kendala dan permasalahan yang ditemukan di kelas IV. Berdasarkan data tersebut maka dilakukan tindakan untuk meningkatkan hasil belajar IPS Tema Indahnya Keragaman di Negeriku siswa kelas IV, tindakan yang dilakukan ialah dengan menggunakan model pembelajaran Course Review Horay.

\section{Deskripsi Hasil penelitian Siklus I}

Hasil post test dari siklus I menunjukkan ketuntasan belajar IPS Tema Indahnya Keragaman di Negeriku siswa kelas IV ialah sebesar 67,74\%, yaitu sebanyak 21 siswa dari 31 siswa sudah mencapai nilai $\geq 75$. Pada aspek kognitif/pengetahuan nilai terendah yang diperoleh siswa ialah 40 dan nilai tertinggi ialah 100. Sedangkan aspek afektif siswa masih cenderung rendah, terutama dalam kerjasama dan menghargai pendapat. Ditunjukkan dengan masih banyaknya siswa yang sedikit enggan dengan anggota kelompoknya sendiri. Untuk aspek keterampilan tidak semua siswa mau menyampaikan jawaban ini menunjukkan bahwa aspek keterampilan berbicara masih cukup rendah. 
Tabel Hasil Belajar IPS Siswa Kelas IV Siklus I

\begin{tabular}{|c|c|c|c|c|}
\hline No & Nama Peserta Didik & Nilai & Tuntas & Tidak Tuntas \\
\hline 1 & Afifah Dwi Maharani & 80 & $\sqrt{ }$ & \\
\hline 2 & Afifah Nur Azizah & 90 & $\sqrt{ }$ & \\
\hline 3 & Akila Farasyakira & 80 & $\sqrt{ }$ & \\
\hline 4 & Alya Azzahra & 80 & $\sqrt{ }$ & \\
\hline 5 & Arrofi Manesa Ismail & 60 & & $\sqrt{ }$ \\
\hline 6 & Attalarafka Yudian.P. & 70 & & $\sqrt{ }$ \\
\hline 7 & Aura Putri Denisa & 80 & $\sqrt{ }$ & \\
\hline 8 & Daffa Reski. M & 80 & $\sqrt{ }$ & \\
\hline 9 & Dina Khumairoh & 100 & $\sqrt{ }$ & \\
\hline 10 & Divo Fakriya & 80 & $\sqrt{ }$ & \\
\hline 11 & Faglhlul Affan & 80 & $\sqrt{ }$ & \\
\hline 12 & Fairuz Athifah Zahra & 80 & $\sqrt{ }$ & \\
\hline 13 & Fajar Anugerah & 80 & $\sqrt{ }$ & \\
\hline 14 & Fikri Aulia Balio $\mathrm{H}$ & 80 & $\sqrt{ }$ & \\
\hline 15 & Genta Seno & 90 & $\sqrt{ }$ & \\
\hline 16 & Hafizha Syafitri & 80 & $\sqrt{ }$ & \\
\hline 17 & Jhonvantio Erlangga & 80 & $\sqrt{ }$ & \\
\hline 18 & Latifa Heny Mayaddah & 60 & & $\sqrt{ }$ \\
\hline 19 & Mezi Syaidatina A & 90 & $\sqrt{ }$ & \\
\hline 20 & Mhd. Abdul Aziz & 40 & & $\sqrt{ }$ \\
\hline 21 & Mubarrar Abid & 80 & $\sqrt{ }$ & \\
\hline 22 & Nadifa Salsabila & 50 & & $\sqrt{ }$ \\
\hline 23 & Nadya Kamilah Idris & 80 & $\sqrt{ }$ & \\
\hline 24 & Puti Nadhiva Azahra & 40 & & $\sqrt{ }$ \\
\hline 25 & Ranga & 60 & & $\sqrt{ }$ \\
\hline 26 & Rendy & 80 & $\sqrt{ }$ & \\
\hline 27 & Rere & 60 & & $\sqrt{ }$ \\
\hline 28 & Revi & 50 & & $\sqrt{ }$ \\
\hline 29 & Reyza & 90 & $\sqrt{ }$ & \\
\hline 30 & Siti & 70 & & $\sqrt{ }$ \\
\hline 31 & Syafika Adhanie & 80 & $\sqrt{ }$ & \\
\hline \multicolumn{2}{|c|}{ Jumlah } & 2300 & 21 & 10 \\
\hline \multicolumn{2}{|c|}{ Rata - rata nilai } & 74,19 & & \\
\hline \multicolumn{3}{|c|}{ Persentase Ketuntasan. } & 45 & $2.26 \%$ \\
\hline
\end{tabular}

\section{Deskripsi Hasil penelitian Siklus II}

Guru memberikan reward berupa lencana bintang dan permen. Siswa diminta kembali ke tempat duduk masing-masing, guru kemudian membagikan soal post test untuk dikerjakan siswa. Soal berjumlah 10 soal pilihan ganda,. Guru dibantu peneliti mengawasi siswa selam kegiatan post test berlangsung. Setelah selesai mengerjakan soal guru mengajak siswa untuk menyimpulkan apa saja yang sudah dipelajari, guru juga memberikan motivasi kepada siswa. Guru menutup kelas dengan berdoa dan mengucapkan salam. 
Tabel Hasil Belajar IPS Siswa Kelas IV Siklus II

\begin{tabular}{|c|c|c|c|c|}
\hline No & Nama Peserta Didik & Nilai & Tuntas & Tidak Tuntas \\
\hline 1 & Afifah Dwi Maharani & 90 & $\sqrt{ }$ & \\
\hline 2 & Afifah Nur Azizah & 100 & $\sqrt{ }$ & \\
\hline 3 & Akila Farasyakira & 80 & $\sqrt{ }$ & \\
\hline 4 & Alya Azzahra & 80 & $\sqrt{ }$ & \\
\hline 5 & Arrofi Manesa Ismail & 80 & $\sqrt{ }$ & \\
\hline 6 & Attalarafka Yudian.P & 80 & $\sqrt{ }$ & \\
\hline 7 & Aura Putri Denisa & 90 & $\sqrt{ }$ & \\
\hline 8 & Daffa Reski. M & 80 & $\sqrt{ }$ & \\
\hline 9 & Dina Khumairob & 100 & $\sqrt{ }$ & \\
\hline 10 & Divo Fakriya & 90 & $\sqrt{ }$ & \\
\hline 11 & Fadhlul Affan & 80 & $\sqrt{ }$ & \\
\hline 12 & Fairuz Athifah Zahra & 80 & $\sqrt{ }$ & \\
\hline 13 & Fajar Anugerah & 90 & $\sqrt{ }$ & \\
\hline 14 & Fikri Aulia Balio H & 80 & $\sqrt{ }$ & \\
\hline 15 & Genta Seno & 100 & $\sqrt{ }$ & \\
\hline 16 & Hafizha Syafitri & 80 & $\sqrt{ }$ & \\
\hline 17 & Jhonvantio Erlangga & 80 & $\sqrt{ }$ & \\
\hline 18 & Latifa Heny Mawaddah & 80 & $\sqrt{ }$ & \\
\hline 19 & Mezi Syaidatina A & 90 & $\sqrt{ }$ & \\
\hline 20 & Mhd. Abdul Aziz & 50 & & $\sqrt{ }$ \\
\hline 21 & Mubarrar Abid & 80 & $\sqrt{ }$ & \\
\hline 22 & Nadifa Salsabila & 60 & & $\sqrt{ }$ \\
\hline 23 & Nadya Kamilah Idris & 90 & $\sqrt{ }$ & \\
\hline 24 & Puti Nadhixa Azahra & 60 & & $\sqrt{ }$ \\
\hline 25 & Ranga & 80 & $\sqrt{ }$ & \\
\hline 26 & Rendy & 80 & $\sqrt{ }$ & \\
\hline 27 & Rere & 80 & $\sqrt{ }$ & \\
\hline 28 & Revi & 70 & & $\sqrt{ }$ \\
\hline 29 & Reyza & 100 & $\sqrt{ }$ & \\
\hline 30 & Siti & 80 & $\sqrt{ }$ & \\
\hline 31 & Syafika Adbanie & 80 & $\sqrt{ }$ & \\
\hline \multicolumn{2}{|c|}{ Jumlah } & 2540 & 27 & 4 \\
\hline \multicolumn{2}{|c|}{ Rata - rata nilai } & 81,94 & & \\
\hline \multicolumn{3}{|c|}{ Persentase Ketuntasan } & $10 \%$ & $12,90 \%$ \\
\hline
\end{tabular}

Berdasarkan pada tabel di atas, tabel hasil belajar IPS pada siklus II mengalami peningkatan dari siklus I. Kenaikan tersebut terlihat dari hasil belajar IPS siswa kelas IV pada siklus II ditunjukkan dengan jumlah siswa yang mendapatkan nilai diatas KKM (75) sudah lebih banyak daripada siklus I. Pada siklus II, siswa yang sudah mencapai batas ketuntasan belajar ialah sebanyak 27 siswa dari 31 siswa atau sebesar $87,10 \%$. Sedangkan siswa yang belum mencapai ketuntasan 4 siswa sebesar 12,90\%, dan mengalami peningkatan sebesar 19,36\%. Nilai tertinggi siswa pada siklus II adalah 100 dan terendah adalah 50, dengan rata-rata kelas 81,64. Berdasarkan pada hasil yang diperoleh dari siklus II terlihat sudah banyak mengalami peningkatan. Peningkatan terjadi dalam berbagai aspek, dalam aspek kognitif, dapat dilihat adanya peningkatan dari hasil tes siklus I nilai rata-rata kelas mengalami peningkatan pada siklus II. Nilai rata-rata kelas pada tes hasil belajar yang diperoleh pada siklus I ialah 74,19 dengan nilai terendah 40 dan tertinggi 100. Dan pada siklus II meningkat menjadi 81,94 dengan nilai terendah 50 dan tertinggi 100.

Pada aspek afektif siswa juga mengalami peningkatan yang baik. Sikap siswa dalam siklus I yang masih sulit bekerjasama dan banyak yang pasif jadi semakin berkurang. Siswa juga semakin menghargai dengan pendapat teman melalui kegiatan 
diskusi. Aspek psikomotor juga semakin meningkat, siswa semakin aktif dalam kegiatan tanya jawab bersama dengan guru, dan semakin banyak yang mulai berani untuk ikut berpendapat. Berdasarkan pada uraian di atas, guru bersama dengan peneliti merasa tindakan sudah cukup untuk dilaksanakan dan akan dihentikan karena indikator sudah tercapai dengan baik, hasil belajar siswa yang telah mencapai diatas KKM sudah lebih dari $75 \%$.

\section{Pembahasan}

Pembahasan hasil penelitian mengenai peningkatan hasil belajar IPS dengan model pembelajaran course review horay siswa kelas IV UPT. SD Negeri 21 Limo Kaum. Berdasarkan pada data hasil pra-tindakan yang sudah dilaksanakan diperoleh hasil bahwa tingkat ketuntasan hasil belajar siswa termasuk rendah. Hasil penelitian ini menunjukkan hasil belajar IPS siswa kelas IV telah mengalami peningkatan. Hasil penelitian yang akan diuraikan adalah data kondisi siswa dari siklus I dan siklus II. Pada aspek kognitif siswa mengalami peningkatan, hal ini ditunjukkan dengan hasil belajar siswa dari pra- tindakan, siklus I, dan siklus II yang mengalami peningkatan. Selain itu juga diuraikan mengenai peningkatan aktivitas guru dan siswa selama pembelajaran berlangsung. Peningkatan ini dapat dilihat berdasarkan tabel serta diagram di bawah ini. Tabel di bawah merupakan hasil peningkatan hasil belajar kognitif siswa dari pra-siklus sampai pada siklus II.

Tabel Peningkatan Hasil Belajar IPS Siswa dari Pratindakan, Siklus I, dan

\section{Siklus I}

\begin{tabular}{|l|c|c|c|}
\hline \multicolumn{1}{|c|}{ Keterangan } & Pratindakan & Siklus I & Siklus II \\
\hline Jumlah Nilai & 1950 & 2300 & $\mathbf{2 5 4 0}$ \\
\hline Rata-rata Kelas & $\mathbf{6 2 , 9 0}$ & $\mathbf{7 4 , 1 9}$ & $\mathbf{8 1 , 9 4}$ \\
\hline Skor Tertinggi & $\mathbf{8 0}$ & $\mathbf{1 0 0}$ & $\mathbf{1 0 0}$ \\
\hline Skor Tertendah & $\mathbf{2 0}$ & $\mathbf{4 0}$ & $\mathbf{5 0}$ \\
\hline Jumlah Siswa Tuntas & 14 & $\mathbf{2 1}$ & $\mathbf{2 7}$ \\
\hline Presentase ketuntasan & $\mathbf{4 5 , 1 6 \%}$ & $\mathbf{6 7 , 7 4 \%}$ & $\mathbf{8 7 , 1 0 \%}$ \\
\hline
\end{tabular}

Seperti yang terlihat dari tabel di atas bahwa terjadi peningkatan aspek kognitif siswa yang dapat dilihat berdasarkan hasil belajar yang diperoleh siswa. Peningkatan ini dapat dilihat dari pra-tindakan, siklus I dan setelah pelaksanaan siklus II. Hasil peningkatan ini dipengaruhi oleh rancangan tindakan serta hasil refleksi. Pada pra-tindakan pembelajaran dilaksanakan masih bersifat biasa dengan metode yang sering dilakukan guru, guru masih menggunakan metode ceramah dan tugas. Pada pelaksanaan pra-tindakan hasil belajar siswa menunjukkan tingkat ketuntasan siswa yang mencapai KKM sebesar $45,16 \%$ dengan 14 siswa tuntas dari 31 siswa dengan nilai rata-rata kelas sebesar 62,90. Hal tersebut menunjukkan bahwa hasil belajar siswa masih jauh dari baik, dengan presentase ketuntasan di bawah $75 \%$ dan nilai rata-rata kelas masih di bawah KKM . Pada pelaksanaan siklus I pembelajaran sudah menggunakan model pembelajaran Course Review Horay, guru menyampaikan materi dengan meminta siswa membaca kemudian dijelaskan. Guru menjelaskan materi dengan mengaitkan pada materi lain dan kurang runtut, siswa dalam membaca bacaan dan mendalami materi juga kurang serius. Selain itu ada siswa yang tidak membaca bacaan dengan sungguh-sungguh. Saat kegiatan tanya jawab masih banyak siswa yang pasif dalam menjawab maupun menanggapi pertanyaan dari guru. Siswa 
hanya terpaku pada materi bacaan dan tidak menanyakan hal yang belum dipahami, serta kurang fokus dalam memahami materi. Berdasarkan hal tersebut hasil belajar siswa pada siklus I menunjukkan jumlah siswa yang mencapai tuntas sebanyak 21 siswa dari total 31 siswa dengan presentase 67,74\% siswa tuntas. Dengan nilai rata-rata kelas siswa meningkat menjadi 74,19 dari sebelumnya yang hanya 62,90.

Siswa yang tidak tuntas ini merupakan siswa yang kurang fokus dan kurang memperhatikan materi,serta tidak aktif selama kegiatan kelompok maupun dalam diskusi kuis berlangsung. Siswa tidak mampu berdiskusi dengan baik dalam kegiatan kelompok maupun ketika menjawab pertanyaan kuis dari guru yang mana kegiatan ini merupakan inti pelaksanaan model CRH. Selama kegiatan tanya jawab juga lebih banyak diam dan tidak menanggapi guru. Siswa antusias untuk kegiatan kuis dan menjawab pertanyaan bersama, namun guru belum maksimal membuat siswa bersemangat dalam mengikuti kegiatan serta penyampaian langkah kegiatan yang belum runtut.

Berdasarkan pada kekurangan tersebut guru bersama dengan peneliti merancang refleksi untuk perbaikan pada siklus II. Refleksi yang dilaksanakan pada siklus II meliputi penyampaian materi pelajaran dengan lebih baik dengan menggunakan slide dan ditunjang oleh video pembelajaran. Siswa menjadi lebih antusias dan fokus dalam memperhatikan materi dari slide dan video yang ditapilkan. Membentuk siswa dalam kelompok yang lebih kecil sehingga kegiatan kelompok lebih maksimal, dan tidak ada siswa yang pasif selama diskusi. Guru memantau siswa lebih baik selama mendalami materi, dan merangsang siswa untuk lebih aktif dalam kegiatan tanya jawab dengan menambah waktu tanya jawab sebelum dan setelah materi. Langkah kegiatan disampaikan dengan lebih baik sehingga siswa jelas dengan apa yang akan dilaksanakan, dan siswa diminta membuat yel-yel, ini semakin meningkatkan semangat siswa dalam kegiatan kuis. Berdasarkan tindakan yang dilakukan dari hasil refleksi terjadi peningkahan hasil belajar siswa pada siklus II.

Hasil belajar siswa dalam aspek kognitif meningkat dari rata-rata kelas yaitu 74,19 menjadi 81,94 serta presentase kentuntasan siswa dengan nilai diatas KKM yaitu $\geq 75$ sebanyak 27 siswa atau $87,10 \%$ siswa tuntas. Nilai rata-rata siswa naik sebanyak 7,75 point dari siklus I ke siklus II. Hasil belajar siswa meningkat dari prasiklus ke siklus I sampai siklus II. Hasil belajar siswa meningkat karena penyerapan materi siswa lebih baik dari sebelumnya. Seperti pendapat Huda (2013:230) bahwa pembelajaran dengan model Course Review Horay dapat membantu siswa dalam memahami konsep dengan baik karena kegiatan kelompok. Siswa mampu memahami konsep dengan lebih baik karena adanya kegiatan diskusi dalam kelompok, untuk menjawab pertanyaan atau soal dari guru.

Peningkatan yang terjadi tidak hanya pada aspek kognitif saja, namun juga pada aspek afektif dan psikomotorik. Peningkatan aktivitas dalam ranah ini diamati selama proses pembelajaran berlansung, terutama aktivitas dan kegiatan guru dan siswa di kelas. Peningkatan aspek tersebut dapat dilihat dari meningkatnya indikator dari aktivitas siswa yang diamati selama kegiatan pembelajaran. Peningkatan ini dinilai berdasarkan lembar observasi yang sudah di buat oleh peneliti. Peningkatan aktivitas siswa yang berhubungan dengan aspek kognitif dan afektif dapat dilihat seperti di bawah ini 
Tabel Peningkatan Nilai Aktivitas Siswa dalam Pembelajaran

\begin{tabular}{|c|c|c|c|c|}
\hline \multirow{2}{*}{ Keterangan } & Siklus I & Siklus II & & \\
\cline { 2 - 5 } & Pert. 1 & Pert. 2 & Pert. I & Pert. 2 \\
\hline Total Nilai & 42 & 44 & 51 & 56 \\
\hline Presentase & $70 \%$ & $73.33 \%$ & $85 \%$ & $93,33 \%$ \\
\hline
\end{tabular}

Diagram Peningkatan Nilai Aktivitas Siswa dalam Pembelajaran. Data diatas didasarkan pada lembar observasi yang dinilai oleh peneliti selama kegiatan pembelajaran. Dilihat dari data diatas terlihat aktivitas belajar siswa semakin baik selama kegiatan pembelajaran. Aktivitas yang ditunjukkan siswa pada siklus I masih cenderung pasif dan tidak fokus selama pembelajaran. Siswa masih banyak yang tidak membaca materi dengan sungguh-sungguh. Siswa tidak ikut bersuara atau berpendapat dalam kegiatan tanya jawab dengan guru, hanya beberapa orang saja yang menjawab sehingga aktivitas tanya jawab masih rendah. Siswa kurang aktif selama berkelompok dengan anggoota kelompok berjumlah 4 sampai 5 masih ada siswa yang tidak aktif berkelompok. Siswa cukup antusias dengan kegiatan kuis, dan mulai menunjukkan aktivitas kelompok dan diskusi lebih baik dari sebelumnya.

Perbaikan yang dilaksanakan menunjukkan adanya peningkatan aktivitas positif dalam berkelompok. Peningkatan tersebut seperti siswa dibuat dalam kelompok lebih kecil sehingga lebih aktif dalam kegiatan diskusi kelompok, siswa lebih antusias dalam kegiatan tanya jawab dengan guru memberikan sedikit pujian dengan kata "bagus", "benar" . Dengan penggunaan media pembelajaran yang lebih interaktif siswa menjadi lebih fokus dan lebih antusias dalam memperhatikan materi yang disampaikan. Kegiatan berkelompok dan kuis siswa diminta membuat yel-yel ini semakin meningkatkan interaksi dengan teman satu kelompok, serta percaya diri. Siswa juga semakin sportif dalam berkompetesi dengan lebih baik selama kegiatan kuis dengan menghargai pendapat temannya. Siswa juga semakin berani mengutarakan pendapat dan jawabannya pada guru pada kegiatan kuis. Keterampilan siswa dalam menyampaikan informasi semakin meningkat dan semakin baik. keterampilan siswa dalam menulis kalimat sudah cukup baik dan meningkat, dimana siswa menuliskan kalimat pada lembar tugas dan jawaban dengan baik. secara bergiliran seluruh anggota kelompok sudah berani untuk mengutarakan hasil jawaban kelompok selama diskusi.

Untuk aspek afektif atau sikap siswa ditunjukkan dalam kegiatan diskusi dapat dilihat siswa sudah sangat baik dalam melaksanakannya. Asepk sikap siswa kerjasama, tanggung jawab selama pelaksanaan kegiatan terlihat sangat baik siswa menunjukkan kerjasama yang sangat baik dalam kegiatan kelompok. Siswa mampu bekerjasama dalam kelompok dengan membagi tugas dan berdiskusi bersama selama kegiatan kelompok. Untuk tanggung jawab siswa terlihat sudah sangat baik, meskipun ada siswa yang masih ada siswa yang membutuhkan bimbingan selama kegiatan berkelompok dan pembagian tugas. Sementara itu sebagian besar sudah mampu berkelompok dan bekerjasama dengan baik dan sangat baik. Untuk aspek percaya diri siswa sudah sangat baik, dilihat dari kegiatan mendiskusikan jawaban setelah kegiatan kuis bersama guru, siswa berbicara dengan lantang dan tegas tidak malu. Serta dalam kegiatan meneriakkan yel-yel siswa melakukan dengan lebih semangat dan lebih antusias dalam menyuarakan yel-yel kelompok masing-masing. Untuk aspek tanggung jawab, guru dibantu dengan peneliti mengarahkan siswa dalam 
pembagian tugas dalam kelompok. Siswa mengerjakan tugas yang sudah dibagikan dan diarahkan guru dengan sangat baik selama kegiatan pembelajaran. Siswa antusias dalam berkelompok selama kegiatan pembelajaran.Siswa menunjukkan sportifitas yang baik dalam bersaing dengan kelompok lain. Siswa mengerjakan tugasnya dengan sangat baik, meskipun masih ada 1 anak yang belum mampu melaksanakan tugas yang dibagikan kepadanya dengan baik, sehingga perlu diberi bimbingan. Ratarata peningkatan dari hasil pengamatan dan lembar observasi pada siklus I rata- rata nilai siswa sebesar $69,8 \%$ dan meningkat menjadi $87,64 \%$.

Untuk aktivitas guru selama kegiatan pembelajaran juga mengalami peningkatan dari pelaksanaan siklus I sampai siklus II. Aktivitas guru ini juga diamati selama proses pembelajaran berlansung dari siklus I sampai siklus II. Dari hasil pengamatan terlihat peningkatan pada kegiatan guru saat proses pembelajran IPS. Peningkatan yang terjadi dapat dilihat seperti pada tabel di bawah.

Tabel Peningkatan Nilai Aktivitas Guru dalam Pembelajaran

\begin{tabular}{|l|c|c|c|c|}
\hline \multirow{2}{*}{ Keterangan } & Siklus I & Siklus II & & \\
\cline { 2 - 5 } & Pert. I & Pert. 2 & Pert. I & Pert. 2 \\
\hline Total Nilai & 52 & 54 & 60 & 68 \\
\hline Presentase & $68,42 \%$ & $71,05 \%$ & $78,95 \%$ & $89,47 \%$ \\
\hline
\end{tabular}

Diagram Peningkatan Nilai Aktivitas Guru dalam Pembelajaran. Data tabel di atas didasarkan pada hasil observasi selama pelaksanaan pembelajaran siklus I dan siklus II. Tabel di atas menunjukkan adanya peningkatan aktivitas guru yang semakin baik dari siklus I sampai siklus II. Pada pembelajaran siklus I, guru belum mengawasi dengan baik saat siswa membaca materi. Waktu untuk kegiatan tanya jawab juga belum maksimal, guru juga tidak mendorong siswa untuk menjawab atau memberikan balikan. Guru juga belum menyampaikan satu langkah kegiatan kuis, sehingga kegiatan tidak berlangsung maksimal. Pemberian reward berupa tepuk hebat belum meningkatkan motivasi anak dalam berkuis. Namun guru sudah melaksanakan pembelajaran dengan baik, dengan memberikan motivasi pada awal pembelajaran dan akhir pembelajaran, serta mengaitkan materi dengan hal-hal disekitar lingkungan siswa. Berdasarkan pada releksi dari siklus I, mengenai kekurangan dalam pembelajran, peneliti bersama guru merencanakan perbaikan untuk pertemuan berikutnya.

Pada siklus II, guru sudah melaksankan perbaikan dengan lebih memperhatikan siswa selama mendalami materi. Guru melaksanakan kegiatan apersepsi dengan sangat baik, serta mengaitkan materi dengan permasalahan di sekitar siswa. Guru juga memberikan motivasi bagi siswa di awal kegiatan, dan tidak lupa untuk menyiapkan siswa belajar. Guru melaksanakan sesi tanya jawab terkait materi sebelum dan setelah siswa membaca materi dan mengamati video yang diputarkan. Guru dibantu peneliti membuat kegiatan membentuk kelompok dengan lebih baik sehingga siswa menjadi lebih antusias untuk dibuat dalam kelompok-kelompok kecil. Guru menyampaikan langkah kegiatan kuis dengan lebih baik, dan mengajak siswa membuat yel-yel, pemberian reward berupa tanda bintang untuk setiap jawaban benar, pemberian pujian, dan mengajak siswa meneriakkan yel-yel kelompok lebih semangat. Guru memberikan motivasi dan penguatan serta mengajak siswa bertanya jawab selam membahas soal kuis, dan pemberian reward berupa lencana bintang. Hal yang dilakukan tersebut berdampak terhadap minat, motivasi serta perhatian siswa selama melaksanakan kegiatan pembelajaran, dan meningkatkan hasil belajar siswa pula. Siswa juga menjadi

12 Lembaga Penelitian dan Penerbitan Hasil Penelitian Ensiklopedia $\quad$ EISSN 2657-0289 PISSN 2657-0297 
lebih antusias ketika guru memberikan pujian sederhana ketika siswa berani menanggapi atau menjawab.

Berdasarkan pada penjabaran dan pembahasan dari hasil penelitian di atas, hasil penelitian menunjukkan bahwa penelitian ini berdampak pada peningkatan hasil belajar siswa. Selain hasil belajar juga dapat meningkatkan aktivitas baik guru maupun murid dalam aspek afektif dan psikomotor. Seperti pendapat Huda (2013:231) bahwa model pembelajaran Course Review Horay dapat meningkatkan semangat belajar siswa, sehingga siswa akan semakin giat membaca materi agar mendapatkan nilai yang baik. Mengingat selama ini guru sering mengajar siswa dengan memberikan penugasan untuk langsung mengerjakan LKS yang dimiliki siswa, guru juga banyak menggunakan metode ceramah di kelas. Hal ini tersebut membuat siswa kurang dalam hal bertukar pendapat untuk semakin mendalami materi.Pembelajaran Course Review Horay menurut Kurniasih dan Sani (2015: 81) merupakan salah satu pembelajaran kooperatif, yang merupakan pembelajaran dengan cara mengelompokkan siswa dalam kelompok kecil.Kelompok kecil ini akan membantu siswa untuk berdiskusi dan bertukar jawaban maupun pendapat selama kuis. Melalui kegiatan tersebut pemahaman siswa akan semakin berkembang, dan meningkatkan pemahaman sebelumnya. Sehingga berdasarkan hasil pembahasan di atas terjadi peningkatan hasil belajar siswa serta aktivitas guru dan siswa di kelas.

\section{Penutup}

Berdasarkan pada hasil penelitian dan pembahasan, maka kesimpulan yang didapatkan dari penelitian ini ialah pembelajaran dengan menggunakan model pembelajaran Course Review Horay pada pembelajaran IPS siswa kelas IV dapat meningkatkan hasil belajar siswa. Hasil peningkatan ini dapat dilihat dari peningkatan aspek kognitif, afektif dan psikomotor siswa. Aspek kognitif ditunjukkan dengan hasil belajar siswa pada pra-tindakan presentase ketuntasan $45,16 \%$ atau 14 siswa nilainya di atas KKM yaitu 75 meningkat pada siklus I menjadi 67,74\% atau 21 siswa yang mencapai nilai di atas KKM. Hasil yang diperoleh pada siklus II ialah $87,10 \%$ siswa sudah mencapai ketuntasan atau sebanyak 27 siswa telah mencapai nilai KKM. Hasil nilai rata-rata siswa pada pembelajaran IPS dari pra-siklus 62,90 meningkat pada siklus I menjadi 74,19 dan pada siklus II meningkat menjadi 81,94. Peningkatan yang terjadi dari siklus I ke siklus II meningkat sebanayak 7,75 point. Untuk aktivitas guru dan siswa meningkat dari sikkus I sampai siklus II, dengan nilai rata-rata aktivitas siswa siklus I sebesar $69,8 \%$ meningkat menjadi $87,45 \%$ untuk aktivitas guru siklus I rata-ratanya sebesar $71,03 \%$ meningkat menjadi $86,18 \%$.

\section{Daftar Pustaka}

Anitah, S. (2010). Strategei Pembelajaran di SD. Jakarta: Universitas Terbuka

Arikunto, S.(2010). Prosedur Penelitian Suatu Pendekatan Praktik. Jakarta: PT Rineka Cipta

Huda, M. (2015). Model-model Pengajaran dan Pembelajaran: Isu-isu Metodis dan Paradigmatis Yogyakarta : Pustaka Pelajar.

Kurniasih, I dan Sani, B. (2015). Ragam Pengembangan Model Pembelajaran: Untuk Peningkatan Profesionalitas Guru. Jakarta: Kata Pena

Kusumah, Wijaya \& Dedi Dwitagama. 2010. Mengenal Penelitian Tindakan Kelas. Jakarta: PT Indeks.

Lilik, S. (2013). Psikologi belajar. Jakarta : Ombak 
Ngalinum.(2013). Strategi dan Model Pembelajaran. Yogyakarta : Aswaja Pressindo .(2016). Strategi dan Model Pembelajaran. Yogyakarta: Aswaja Pressindo

Priansa, D.J.(2017). Pengembangan Strategi dan Model Pembelajaran: Inovatif, Kreatif dan Prestatif dalam Memahami Peserta Didik. Bandung:Pustaka Setia

Purwanto.(2010). Evaluasi Hasil belajar. Yogyakarta: Pustaka Pelajar

Rumini, S. dkk.(1998). Psikologi Umum. Yogyakarta: Fakultas Ilmu Pendidikan

IKIP Yogyakarta

Sugihartono, dkk..(2013). Psikologi Pendidikan. Yogyakarta: Universitas Negeri Yogyakarta

Sumantri, M.S.(2013). Strategi Pembelajaran Teori dan Praktik di Tingkat Pendidikan Dasar.Jakarta: PT Rajagrafindo Persada

Suprijono. A.(2016).Cooperative Learning Teori \& Aplikasi PAIKEM. Yogyakarta : Pustaka Pelajar Pelajar

(2016). Model-model Pembelajaran Emansitoris. Yogyakarta: Pustaka

Suryabrata, Sumadi. 2012. Psikologi Pendidikan. Jakarta: Raja Grafindo.

Trianto.(2010). Model Pembelajaran Terpadu- Konsep, Strategi dan implementasinya dalam Kurikulum Tingkat Satuan pendidikan..Surabaya: PT Bumi Aksara

Wahidmurni.(2017). Metodologi Pembelajaran IPS Pengembanga Standar proses pembelajaran IPS di Sekolah/Madrasah. Yogyakarta: Ar-ruzz Media

Winataputra.(2007). Materi Pokok Pembelajaran IPS di Sekolah Dasar. Jakarta: Universitas Terbuka 